\section{Currents of Change: Early Childhood Education in 2001}

\section{LINDA MITCHELL}

\section{Abstract:}

This article argues that the rights of children should be at the heart of early childhood education policy development. It describes the free market framework inherited by the current government, highlights inequalities for children in income and participation in early childhood education and describes policy initiatives. These are analysed against yardsticks for effective government policy for children. The article concludes that there is currently a new valuing of early childhood education, and significant shifts in policy are in train. However, key to the success of these shifts will be the government's willingness to prioritise early childhood education and make hard decisions about planning, co-ordination and funding, or the policies will be unworkable.

E arly childhood education in New Zealand has new political priority. The government has expressed strong commitment to the sector. In addition, the decision that the Minister of Education, not an associate, will hold the early childhood education portfolio for the long term, sends strong signals of its determination:

It's been seen as a sidebar to the education sector rather than an integral part of it. In the last six years there have been five Ministers with responsibility for early childhood education. I want to make sure that that kind of stop start approach does not continue. Because early childhood education is too important. (Mallard, 2000)

A number of new early childhood education policies have been introduced, and the government is considering recommendations for further strategies made in the long term strategic plan developed by the sector at the Minister's request. (Early Childhood Education Long Term Strategic Plan Working Group, 2001).
This article comments on the policy framework which the current government inherited, describes some information about inequalities in income and participation in early childhood education, and analyses policy initiatives that are being undertaken or considered. Do these put children's rights and interests at the heart of policy development? To what extent will they result in fundamental change to the valuing of, and governmental support for, early childhood education?

Children's Rights and Interests At the Heart of Policy Development

ensuring the rights of children must begin at the start of life.

The time of early childhood should merit the highest priority attention when responsible governments are making decisions about laws, policies, programmes and money. Yet tragically, both for

children and for nations, these are the years that receive the least. (UNICEF, 2001, p. 9)

Many countries have made a formal commitment to the rights of children by ratifying the United Nations Convention on the Rights of the Child. How to enact that commitment generally, and in the early childhood sector specifically, has been analysed and discussed internationally. While different countries will develop different practices and strategies for enactment depending on their contexts, consensus on a number of principles for policy seems to be emerging.

These principles are:

- a clear policy framework based on goals for children, which is coherent, consistent and integrated across policy areas;

- comprehensive data collection, monitoring and analysis;

- investing in children and giving them budgetary priority, through financing services and infrastructure (Hodgkin \& Newell, 1996; OECD, 2001; Parliamentary Assembly of the Council of Europe, 1996).

Some specific structures, such as appointing an independent commissioner for children, are also recommended (Hodgkin \& Newell, 1996; Parliamentary Assembly of the Council of Europe, 1996).

In relation to the early childhood sector, specific recommendations have been made. The OECD report on early childhood education and care in twelve OECD countries (2001, p. 127) described the key structural elements for high quality, accessible services as: clear policy frameworks, effective governance and monitoring processes, supporting 
and training professional staff, and adequate funding and financing mechanisms. These are similar to the conditions recommended by the European Commission Network on Childcare (1996) to achieve objectives for the development of services for young children:

- a policy framework for service provision;

- coordination of responsibility for services;

- a curricular framework;

- appropriate staffing and staff pay (including training and pay);

- appropriate physical environments;

- infrastructure for planning, monitoring, support, training, research and development;

- adequate financing of services and infrastructure (pp. 5-6).

New Zealand is one of 190 countries that has ratified the UN Convention on the Rights of the Child and has had a statutory Commissioner for Children for the last 13 years. The government has now also committed itself to mainstreaming human rights considerations into all policy development and implementation. The Hon. Margaret Wilson, Attorney General, stated at the third reading of the Human Rights Amendment Bill:

The second main achievement of this Bill is to require government and parliament to consider all human rights issues at the start of the policy process. Good governance, fairness and equality underpin social cohesion and long term economic development.

The government and wider public sector must realise that the early inclusion and consideration of human rights principles in policy development makes that policy more sustainable. Early consideration of human rights principles leads to good public policy. (Wilson, 2001, p. 2)

In mainstreaming human rights issues into policy and implementation, specific focus and priority should be placed on children's rights, because of the importance of children for society and because children need adults to advocate for their interests. New Zealand has been informed that it needs to make crucial improvements in its approach to policy, practice and legislation in order to uphold the rights of the child. In 1997, the United Nations Committee on the Rights of the Child reviewed the situation of children in New Zealand and recommended the need to:
- develop a comprehensive policy or plan of action for children and young people;

- review all government policy, practice and legislation and bring these into line with the Convention;

- give priority to children in budget allocation;

- gather better disaggregated statistical data and information on the situation of children;

- study the impact of economic reforms on children;

- reduce inequalities between Maori and non-Maori.

(United Nations Committee on the Rights of the Child, 1997)

The Ministry of Youth Affairs (2000) reported on how New Zealand is working to address these issues, although it acknowledged progress had been slow. The rights and needs of children have only rarely been at the forefront of early childhood education policy development. Nevertheless, there are two significant developments which could be described as putting children's rights first, and which mark New Zealand as a world leader in these aspects.

One is the integration of care and education and co-ordination of all early childhood education services under the Department of Education in 1986. This acknowledged that children's "care" and "education" needs are not separable, and promoted some coherence for early childhood education services and therefore for children, by bringing education services under a unified administrative framework.

A second development was the publication in 1996 of a national early childhood curriculum (Te Whāriki) founded on aspirations for children "to grow up as competent and confident learners and communicators, healthy in mind, body and spirit, secure in their sense of belonging and in the knowledge that they make a valued contribution to society" (Ministry of Education, 1996, p. 9). Te Whāriki's aspirations acknowledge that children themselves are not passive dependants but active learners and citizens.

In the next section, the policy framework of the 1990s for early childhood education in New Zealand is discussed and inequalities and discrimination are highlighted.

\section{The Inherited Policy Framework}

The current government has inherited early childhood policies that flowed from a free-market framework in which parents were 
conceptualised as consumers choosing from an increasingly privatised market. During the 1990s the government had little involvement in service planning and provision. As a consequence, there are gaps and duplications in service provision, and access by different groups is variable (Department of Labour/NACEW, 1999; Early Childhood Education Project, 1996; Early Childhood Education Long Term Strategic Plan Working Group, 2001). There has been an expansion in commercial for-profit education and care centres, to the extent that now they number more than half of all such centres. In 2001 there were 848 for-profit centres (operated by private owners or private trusts) and 705 community-based services (Ministry of Education, 2001a).

There are major problems with the current funding arrangements: insufficient levels of funding, difficulties created by attendance rules and by a relatively uniform formula which does not recognise costs of different types and size of services, and administrative burdens. These have been highlighted in forums involving the sector from 1994 to 2001 (Hanna, 1994; Early Childhood Education Long Term Strategic Plan Working Group, 2001; Early Childhood Education Project, 1996; Mitchell, 1996).

In 1995, representatives from the largest national early childhood education organisations for each early childhood service type worked together to research and develop proposals on the structures and funding required to deliver high quality early childhood education services for young children. The focus was on community-based services. It was felt that the government of the day was not consulting those in the field or responding to the sector's concerns and that there appeared to be an erosion of high quality early childhood education. The report of this group, Future Directions (Early Childhood Education Project, 1996) criticised the work of government agencies for:

- inadequate communication and coordination between government agencies and within government agencies;

- inaccurate and inconsistent information from government agencies;

- inadequate involvement of the sector in policy decisions at national, regional and local levels (p. 46).

The report also emphasised the importance of specialised early childhood qualifications and experience of personnel. It criticised the state infrastructure, because of:

- low regulated standards, inappropriate and ineffective monitoring of standards and failure to act effectively on low quality centres;
- limited governmental goals for early childhood education, and poor information statistics and research (p. 46).

These concerns continued to be raised in 2001. There is "no consistent infrastructure for supporting services" (Early Childhood Education Long Term Strategic Plan Working Group, 2001, p. 7).

The previous government's equivocation about state responsibility in the early childhood sector and its moves to "downsize" that responsibility were displayed in the removal in April 1997 of kindergarten teachers and associations from the State Sector Act.

The model of state involvement in the 1990s was of a "minimal state" in which the family was regarded as largely responsible for the care [and education] of dependants, as opposed to a "supportive state" that viewed care [and education] as a co-operative effort between families and the state (Royal Commission on Social Policy, 1988, p. 214).

There is evidence of two main effects that have flowed from this individualist relationship between the state and the early childhood sector.

The first relates to who was involved in educational decision-making at local and national levels. Popkewitz (1996) calls these the "actors" in the educational arena. In early childhood services, there were few opportunities for collaborative work outside the immediate service's community and little opportunity for substantive involvement in policy work. A focus on individualism extended to teachers' conditions of employment where the Employment Contracts Act discriminated against collective bargaining (ILO, 1994; NZEI Te Riu Roa, 2000). At national level, teachers, teacher educators, employers, parents and their representative organisations were not consulted in major areas of policy making. Such an approach served to isolate the individual and prevented an exchange of experiences and ideas from which to learn.

The second effect was that the government's funding, regulatory and advisory systems operated in favour of those who could make the system work for them, or who did not have extraordinary features requiring extra support or resources. These systems made it harder for those who couldn't reach the goal posts - hence, for example, the large number of unlicensed Pacific Islands centres, and financial difficulties for small rural centres (Early Childhood Education Project, 1996). These systems bore little relationship to the work and roles of early childhood education, to the conditions needed to support the curriculum or to the 
ideals of equity and access. I have argued that these effects had their foundations in the 1989 "Before Five" policy document and its implementation plans which failed to provide structural underpinning for its aims of equity and partnership (Mitchell, 1999).

\section{Information on Inequalities in Income and Early Childhood Participation}

Early childhood education is set within a wider context which influences the health and well-being of children and their families. Consideration of children's economic circumstances and barriers to accessing early childhood services sets a background for discussion of policies. The following information provides evidence of income inequalities in the lives of children and inequalities in participation in early childhood education. Some key trends are as follows.

Income distribution

During the 1980s and 1990s family income inequality in New Zealand increased substantially, relative to levels in other OECD countries (O'Dea, 2000). Proportionally greater concentrations of households with children or dependent young people are in lower income quintiles (Mowbray, 2001). In 1996, 26 percent of all children under the age of 15 years were in the bottom income decile and 23 percent in the next to bottom (Statistics New Zealand, 1999). The children of one parent families, and Maori, Pacific Islands and Asian parents were more likely be in low income families (Statistics New Zealand, 1998). Mayer (2000), in research in the United States, found that inequality affects children's "interpersonal comparisons" which in turn affect their educational attainment.

Level of income also affects children's educational attainment. O'Dea reported that "the poor appear to have got poorer in real income terms in the last 15 years, by perhaps $5 \%$ on average; a significant reduction in living standards" (2000, p. 56). He stated that analysis of data from the Christchurch Health and Development Study shows that, over a 14 year period, 2 percent of the children in the study experienced chronic poverty (spells never separated by more than a year) or poverty for the whole 14 years. Another 15 percent experienced poverty for just one year, or only occasionally.

Whether measured by physical and mental development, health and survival rates, educational achievement or job prospects, incomes or life expectancies, those who spend their childhood in poverty of income and expectation are at a marked disadvantage (UNICEF, 2000, p. 3).

Participation in early childhood education

There are also inequalities in access to early childhood education services, associated with location, availability of appropriate services and cost (Department of Labour/NACEW, 1999; Early Childhood Education Project, 1996). The Department of Labour/NACEW childcare survey outlined demographic features of the groups which had disproportionately lower attendance in early childhood education as: children from low income families, from families with parents not in paid employment and from Maori, Pacific Islands and ethnic groups other than European. The survey identified barriers as: cost, lack of informal care by someone known, lack of suitable hours, lack of local services, lack of age-appropriate services, transport difficulties, waiting lists and lack of quality programmes. A dominating theme in the submissions on the long term strategic plan was that cost is a barrier to participation (Ministry of Education, 2001b). Almost one in six (15\%) of parents in the New Zealand childcare survey stated that problems accessing early childhood education and care had affected their ability to participate in employment (Department of Labour/NACEW, 1999).

\section{Policy initiatives}

In this next section, new and proposed policy directions are described and discussed against yardsticks generated from the earlier outline of key principles:

- Is there a clear, coherent integrated framework based on the needs and rights of children?

- What infrastructure supports comprehensive data collection, training, monitoring, research and development, planning and support?

- What funding arrangements and budgetary allocations are present to enable all children to participate in high quality early childhood education services?

- What support is there for the people who work in early childhood services? In this article, the focus is on staffing requirements, pay and working conditions and advisory support for paid staff.

Several far-reaching developments have taken place in early childhood education and related policy areas since 1999. While some of these, such as increases to bulk funding rates, have not altered the structural 
underpinnings for early childhood services, others are seeking to address some structural issues in the areas of policy planning, funding, staffing (employment, professional standards, training and qualifications), and access and provision. The early childhood education initiatives are consistent with the government's broad goals for education - to improve quality and to increase participation in quality early childhood services. As well, changes are recommended in the state sector aimed at better integration between and within government agencies which impact on early childhood education services.

\section{An integrated policy framework}

An initiative to provide strategic goals and a framework for policy was the development during 2000 and 2001 of an early child hood education long-term strategic plan by a working group of 30 individuals and organisation representatives. I was a member of the working group and of a subsequent "technical working group" that was asked to prioritise strategies within a $\$ 100 \mathrm{~m}$ funding budget. The introduction to the plan stated that its twenty strategies represent three major shifts in policy direction.

First, enhancing policies at the national level and contexts at the local level to facilitate the implementation of Te Whāriki in its fullest sense.

Second, changing structures, systems and regulations so they become better $\mathrm{Co}-$ ordinated to support the contributions made by parents, teachers and educators to children's early learning and development....

Third, transforming the role of Government within the early childhood education sector so that early childhood education is provided in partnership with Government. (Early Childhood Education Long Term Strategic Plan Working Group, 2001, p. 4)

The plan covers four inter-related areas:

- participation, engagement and access;

- collaborative relationships (e.g., improving programme and agency co-ordination, improving coherence and continuity of education from birth to 8 years, informing quality and participation goals through a programme of research);

- quality early childhood education services;

- sustainable early childhood education services.
Proposed strategies aim to address major issues of concern about the current situation and to bring together the diverse services into one framework. These features give the plan some coherence. The longterm ten year timeframe offers a departure from year to year planning that has occurred in the past.

However, there are shortcomings. The European Commission Network on Childcare (1996) proposed that a comprehensive policy framework:

identifies principles and goals for services, it sets out a programme to implement the policy, it outlines strategies for implementation, it lists specific targets, and it does all this within a clear resource framework. (p. 10)

The New Zealand plan falls down by giving insufficient specificity about priorities, recommendations, government resourcing and how the plan will be evaluated. While the plan provides sequencing for implementation and some strategies are clear (e.g., on staff:child ratios and teacher qualifications), others are obscure. There is insufficient detail about which particular strategies are to be implemented, when and how. Many of those who made submissions to the draft plan also criticised it for lack of specific information (Ministry of Education, $2001 b)$. The government's decisions on the plan, its ability to shape it into a clear programme and its willingness to address all the areas in an integrated way will be critical for its impact.

\section{Infrastructure support}

In this section two issues are discussed. The first is the ability of government agencies and Crown entities to work effectively with early childhood services. The second is the government's infrastructure of support (data collection, training, monitoring, research and development, planning and support).

Government agency coherence, communication and integration Structures and practices to create better coherence and communication between government agencies and government agencies and services have been proposed in some areas related to early childhood education:

- A review of the relationship between the Crown and Te Kohanga Reo National Trust (Crown/Kohanga Reo National Trust Joint Working Group, 2001) proposed that the Trust, Ministry of Education and Te Puni Kokiri enter into a tripartite relationship agreement so that the three organisations could better work 
together to support the kaupapa ${ }^{1}$ of kohanga. This proposal was made in acknowledgement that the goals, aspirations and work of kohanga are shared across both government departments. Relationship managers for each organisation were proposed to ensure open communication and sharing of information, provide a contact point and negotiate with other agencies.

- An evaluation of two of Early Childhood Development's (ECD's) services (Mitchell \& Mara, 2001) found evidence that there were not common understandings of roles and responsibilities, interpretations of standards or effective communication between Ministry of Education and ECD in some of their overlapping areas of work. It recommended development of effective communication systems and frameworks of understanding and that the form of the relationship between the Ministry of Education and ECD should be examined. The latest ECD Annual Report $(2001$, p. 8) noted that an external review of ECD had given emphasis to issues including the relationship between the Ministry of Education and ECD and the strengths and weaknesses of the Crown entity form as applied to the early childhood sector. As a result, ECD had developed a regional structure to locate planning and decision-making closer to the action, manage staff resources more effectively and build capacity to monitor trends and issues.

Some measures have already been taken to make government agencies more responsive to the needs of people and services, and to ensure better integration of their work with other government organisations.

- A review of Special Education 2000 policy (Wylie, 2000) resulted in the Specialist Education Services being disbanded and becoming a group within the Ministry of Education in February 2002, and this is expected to provide more continuity in Early Intervention.

- A review of the Education Review Office (ERO) (Review Committee, 2000) outlined three key principles underpinning recommendations: reviews should adopt improvement rather than compliance principles; advice must be provided to an early childhood centre following a review; ERO staff should be culturally aware and its services should be culturally appropriate. In addition it pinpointed the need for the ERO and Ministry of Education to improve their relationships and for this to be monitored. The review recommendations have been accepted.
For the public service in general, the government has reviewed the public management system and "how well it responds to the needs and expectations of Ministers and of citizens" (Advisory Group on the Review of the Centre, 2001, p. 4). Of particular interest to early childhood education is that it has made proposals on how to get greater integration of service delivery when a number of agencies are involved; how to "tackle fragmentation" and improve alignment between policy and operations in the state sector and how to improve the systems by which state servants are trained and developed. While it is too soon to say what will happen, the recognition of these problems is promising.

State infrastructure

If we are to move away from a system where individual services are alone responsible for their own performance to one where mutual responsibilities are held by the government and early child hood centres, then "strengthening the state infrastructure" needs to be treated as a key area for government investment.

Strengthening the state infrastructure is highlighted in many of the long term plan strategies; for example, in its recommendations for improved capacity and quality of teacher education, planned provision, a coherent system of advice and support, and strengthening research.

In addition, some new related policy has been announced in respect to planning and provision: that new school sites will now include provision for early childhood centres. This represented a shift from previous years in re-establishing a governmental role not held since 1989 for early childhood education provision (Mallard, 2001).

\section{Funding arrangements and budgetary allocations}

Substantial government funding for services is necessary to enable access to quality early childhood education services for all children whose parents wish them to attend.

Free education

Chief Human Rights Commissioner Rosslyn Noonan has said that New Zealand's failure to ensure all children have access to quality early childhood education could amount to a form of discrimination, because many children are missing out on the opportunity to attend a good early childhood education service.

Article 29 of the UN Convention on the Rights of the Child states that the education of the child shall be directed to, amongst other things, 
"the development of the child's personality, talents and mental and physical abilities to their fullest potential."

In the New Zealand context the results of the Competent Children longitudinal study and other research confirms the very significant impact of quality early childhood education on a child's achievement at primary school. On that basis early childhood education can be viewed as an implicit element of the right to free primary education provided for in the international Conventions that New Zealand has ratified. (Noonan, 2001, p. 65)

The long-term strategic plan proposed an entitlement to a "reasonable amount" $^{\prime \prime}$ of free early childhood education for all children, implemented in stages. The first stage would be an entitlement for free early childhood education for children aged 3 and 4 years of age up to 15 hours per week, but the plan stated that this was "beyond the financial constraints of the government" at this stage (p. 44).

Implementation of this goal is crucial to a system based on children's rights. In making access to free early childhood education a statutory right, New Zealand would remove significant cost and access barriers, be consistent with "rights" conventions and join leading OECD countries $(\mathrm{OECD}, 2001)$ in placing priority on children's educational interests.

Funding arrangements

The long term strategic plan proposes a change from the current funding arrangement to a system that is linked to and responsive to actual costs in each service type. There are five key elements that mark the proposals as different from the current regime:

- a new formula would be developed that takes into account staffing, operating and advisory/support costs for service types;

- government funding would be responsive to cost factors and there would be a review mechanism for major changes in cost factors;

- a system of equity funding would be implemented;

- the Ministry of Education would develop guidelines and a model for accounts of early childhood services;

- the Minister of Education would provide an annual consolidated report on the performance of early childhood services to the government.

There was a great deal of support in the consultations on the draft plan for these changes in funding levels and the funding model. But the plan fell short of giving specific proposals on a new funding system, an issue that dominated responses from those respondents who identified gaps in the "sustainability" strategies (Ministry of Education, 2001b).

Base funding

The plan did not recommend the level of funding to be provided by the government but stated:

Funding levels would be sufficient to cover the cost of well resourced learning environments, fairly compensated and well qualified staff, a fair and equitable level of support for parents' and whanau provided services, and inclusion of children with special needs. Funding would ensure that participation in ECE does not depend on parents' ability to pay. (Early Childhood Education Strategic Plan Working Group, 2001, p. 31)

This statement implies that the government would provide funding to cover substantive costs. On the other hand, the plan noted that the goal of free education was outside the financial constraints of the government at this stage (i.e., families would need to pay). The plan is inconsistent in this aspect.

Would the proposed arrangements for base funding make a difference to quality and access? A new formula based on key cost factors should alleviate financial problems for all services, especially for those that have high operating costs relative to the number of children (e.g., because of factors such as small size, location or staff profile). This in turn would enhance their viability. Services should be able to offer enhanced quality if the formula is tagged to structural features of quality (e.g., qualified staff, staff pay, improved ratios) and used for these purposes. Services should also be protected against arbitrary cuts in funding or loss of purchasing power (as happened during the early 1990 s when bulk funding rates were frozen or reduced).

However critical issues remain:

- how much government funding is provided and whether it is sufficient to cover costs;

- whether services actually use the funding to enhance quality and access;

- what cost indices are used and how responsive is the formula to changes in these. There are important issues to address in this respect, such as how to set a staffing cost index in a system where there are variable rates of pay and de-centralised bargaining except in the kindergarten sector. Should bargaining be centralised? 
Should services be paid actual staffing costs? Should staff be paid centrally?

- how funding is delivered, and accountability for spending;

- whether fees are payable, and if so, how these are set and at what level. Should fees be capped at certain levels as happens in some countries (OECD, 2001)?

- whether for-profit services should be eligible for government funding on the same basis as community-based services.

The plan is not sufficiently strong or precise in respect to its recommendations on funding to answer these questions, or to gauge what difference it would make to viability of services, access or quality of education.

\section{Equity funding}

This is not true of proposals for equity funding, as a new equity funding system for early childhood education was implemented on March 5, 2002. It is intended for services that are in low socio-economic communities, have significant numbers of children with special educational needs or are from non-English speaking backgrounds, are based on a language and culture other than English or are in isolated areas. Equity funding is intended to reduce educational disparities between different groups, reduce barriers to participation amongst under-represented groups, and support services to raise their level of educational quality (Ministry of Education, 2001c).

There is clear evidence that children from low income homes face barriers to learning at school (NZCER, 2002). The Competent Children longitudinal project (Wylie, Thompson \& Lythe, 2001) showed that at age five years children whose final early childhood education centre served mainly children from low income homes scored lower than others on a range of cognitive competencies. Strong patterns of association persisted over time after taking into account maternal qualifications and family income. At age ten years, children whose last early childhood centre served mainly children from middle income homes had higher scores on average for literacy, mathematics, communication, logical problem solving, social skills with adults and perseverance. A large difference of around ten percentage points existed between them and children who had attended centres serving mainly children from low income homes. There was an even greater difference of 20 percentage points for mathematics and reading comprehension.

These findings lend strong support for the need for some additional resourcing and support for services serving mainly low socio-economic areas. Equity funding may assist early childhood centres to better meet children's needs in these services but does not replace the importance of adequate base funding for all services.

\section{Staffing, employment, training, pay and conditions}

Changes have occurred in industrial legislation through the passing of the Employment Relations Act which covers paid staff in early childhood services. The Act is intended to promote collective and good faith bargaining and recognise the role of unions. With the passing of the Act, an amendment was made to bring kindergarten teachers back under the State Sector Act. Effectively, this changed the relationship between teachers and government for negotiating the collective agreements covering kindergarten teachers, head teachers and senior teachers. For the purpose of bargaining the government is the employer. As part of the 2000-2002 terms of settlement for the collective agreement negotiated with the union (NZEI Te Riu Roa) the government committed itself to the implementation of pay parity for kindergarten teachers and the establishment of a ministerial working group to establish benchmarks with school teachers and recommend on implementation. The working group has reported to the Minister but the report has not yet been released. Key issues are whether negotiated benchmarks reflect the value and responsibilities of kindergarten teachers in relation to primary and secondary teachers and how and when teachers in the wider early childhood sector achieve pay parity.

There have been some moves to raise qualifications and teaching standards in the early childhood education sector. The Education Standards Act 2001 established a Teachers Council "to provide professional leadership in teaching, enhance the professional status of teachers in schools and early childhood education, and contribute to a safe and high quality teaching and learning environment" (Education Standards Act, 2001, 10A, 139AA, p. 33). (This was launched in February 2002.) An early childhood education advisory group is part of the Council. A new staff training requirement is for "persons responsible" in early childhood centres and co-ordinators of home-based care networks to hold a Diploma of Teaching ECE or its equivalent within a 
timeframe of 2002 for those new to the role and 2005 for those in the role at 2001 .

There is clear evidence that the pay, working conditions, training and qualifications of staff are key determinants of the quality of education (Smith, Grima, Gaffney \& Powell, 2001). This is another priority area for government investment.

\section{Conclusion}

Helen May said that:

the rhetoric of the politician and the advocate might at times accommodate a similar language and rationale, but they are based on different assumptions: social and political change [a dream] versus social political order [political gaze]. It is this contradictory interface which makes up the politics of early childhood. A few examples of early childhood rhetoric include times of accommodation across the "dream" and the "gaze" which creates the possibility of a window for political change, as well as times of resistance and political stalemate. (2000, p. 53)

Will 2002 be merely a window for political change or does it herald the beginning of a new era? Evidence discussed above shows that significant shifts in thinking and action are starting to happen. The "rights based" approach to policy development and implementation, a new acceptance of greater state responsibility for early childhood education, efforts to strengthen integration between and within government departments and an approach to policy development that is open and consultative, are refreshing changes. The environment has shifted; there is a new valuing of early childhood education. But key to the success of these shifts will be the government's willingness to prioritise early childhood education so that all children can access quality services. Hard decisions need to be made about details of planning, co-ordination and funding. Financial resources must be available for services and for the infrastructure to support them or policies will be unworkable. A course needs to be steered with long term aims in sight. Reaching the goal of free high quality early childhood education would go a long way towards ensuring equal access for all young children. Children are citizens and their contribution to society now and in the future can be strengthened through their participation in quality early childhood education.

Note

1. Kaupapa - Maori word meaning "philosophical beliefs".

\section{References}

Advisory Group on the Review of the Centre. (2001). Report of the Advisory Group on the Review of the Centre. $<$ www.ssc.govt.nz/searchset.htm >

Crown/Te Kohanga Reo National Trust Joint Working Group. (2001). Review of the relationship between the Crown and Te Kohanga Reo National Trust. Report to the Ministers of Education and Maori Affairs. Wellington: Ministry of Education.

Department of Labour/National Advisory Council on the Employment of Women (NACEW). (1999). Childcare, families and work. The New Zealand childcare survey 1998. Wellington: Labour Market Policy Group, Department of Labour.

Early Childhood Education Long Term Strategic Plan Working Group. (2001). Final report of the strategic plan working group to the Minister of Education. Wellington; Ministry of Education.

$<$ www.minedu.govt.nz $>$

Early Childhood Education Project. (1996). Future directions: Early childhood education in New Zealand. Wellington: NZEI Te Riu Roa.

Education Standards Act. (2001). Wellington: New Zealand Government.

European Commission network on childcare and other measures to reconcile employment and family responsibilities. (1996). Quality targets in services for young children. Brussels: European Commission Equal Opportunities Unit.

Hanna, P. (1994). A report of the 1994 "Speaking Directly" early childhood education conference. Wellington: Ministry of Education.

Hodgkin, R., \& Newell, P. (1996). Effective government structures for children. London: Calouste Gulbenkian Foundation.

International Labour Organisation. (1994). Case No 1698. Complaint against the Government of New Zealand presented by the New Zealand Council of Trade Unions (NZCTU). Geneva: International Labour Organisation.

Mallard, T. (2000, April 28). Speech to the Early Childhood Council. <www.executive.govt.nz/speech.cfm?speechralph $=30921 \& S>$

Mallard, T. (2001, October 13) New school sites to include early childhood provision.

$<$ www.executive.govt.nz/speech.cfm?speechralph $=32687 \& S>$ 
May, H. (2000, July). Social and political change versus social and political order. Conference proceedings of the Early Childhood Millennium Conference, NZEI Te Riu Roa, Wellington.

Mayer, S. (2000). How did the increase in income inequality between 1970 and 1990 affect American children's educational attainment? <www.harrisschool.uchicago.e...lications/briefs/pb_vol1_num3.html>

Ministry of Education. (1996). Te Whāriki. Wellington: Learning Media.

Ministry of Education. (2001a). Number of education and care centres by authority 1998-2001. Wellington: Ministry of Education.

Ministry of Education. (2001b). Analysis of submissions received on the consultation document for the development of the strategic plan for early childhood education. $<$ minedu.govt.nz/web/document/document_page.cfm?id=6524\&p=1037.5>

Ministry of Education. (2001c, November 16). Early childhood equity funding. Circular 2001/24. Wellington: Ministry of Education.

Ministry of Youth Affairs. (2000). Children in New Zealand. Wellington: Ministry of Youth Affairs.

Mitchell, L. (1996). Crossroads - Early childhood education in the mid-1990s. New Zealand Annual Review of Education, 5, 75-92.

Mitchell, L. (1999, June). Before Five: The price of partnership. Paper presented at the conference, "A decade of reform in New Zealand: Where to now?" University of Waikato, Hamilton.

Mitchell, L. \& Mara, D. (2001). Evaluation of two ECD services: Licensing and chartering advice and support; advice and support to licence exempt playgroups. (Forthcoming).

Mowbray, M. (2001). Distributions and disparity. New Zealand household incomes. Wellington: Ministry of Social Policy.

New Zealand Council for Educational Research. (2002). Submission to the New Zealand House of Representatives "Inquiry into decile funding". Wellington: NZCER.

NZEI Te Riu Roa. (2000). Submission on the Employment Relations Bill. Wellington: New Zealand Educational Institute.

Noonan, R. (2001). Early childhood education - a child's right? Proceedings of conference "Early Childhood Education for a Democratic Society", New Zealand Council for Educational Research, Wellington.
O'Dea, D. (2000). The changes in New Zealand's income distribution. Working Paper 00/13. Wellington: The Treasury.

OECD. (2001). Starting strong: Early childhood education and care. Paris: OECD.

Parliamentary Assembly for the Council of Europe. (1996). Recommendation 1286 on a European strategy for children. Adopted 24 January. <http://stars.coe.fr/ta/ta96/EREC1286.htm>

Popkewitz, T. (1996). Rethinking decentralization and state/civil society distinctions: The state as a problematic of governing. Journal of Educational Policy, 11(1), 27-51.

Review Committee. (2000). A review of the roles and responsibilities of the Education Review Office. Report to the Minister of Education Wellington: Ministry of Education. <www.ero.govt.nz>

Royal Commission on Social Policy. (1988). The April Report. Vol.III, Future directions. Wellington: The Royal Commission on Social Policy.

Smith, A., Grima, G., Gaffney, M., \& Powell, K. (2000). Strategic research initiative literature review: Early childhood education. Wellington: Ministry of Education.

Statistics New Zealand. (1998). Families and households. Wellington: Statistics New Zealand.

Statistics New Zealand. (1999). Incomes. Wellington: Statistics New Zealand.

United Nations Committee on the Rights of the Child. (1997). Concluding observations of the committee on New Zealand. Geneva: United Nations.

UNICEF. (2001). The state of the world's children 2001: Early childhood. New York: UNICEF.

Wilson, M. (2001). Human Rights Amendment Bill. Speech notes: 3rd reading. $<$ www.executive.govt.nz/speech.cfm?speechralph $=36866 \& S>$

Wylie, C., Thompson, J. \& Lythe, C. (2001). Competent children at 10: Families, early education and schools. Wellington: New Zealand Council for Educational Research.

Wylie, C. (2000). Picking up the pieces. Report of Special Education 2000. $<$ www.executive.govt.nz/dalziel/index.html > 
The author

Linda Mitchell is a senior researcher at the New Zealand Council for Educational Research. In 2001 she was a member of the Early Childhood Education Long Term Strategic Plan Working Group and a Crown representative on the Crown/Te Kohanga Reo National Trust Joint Working Group on the "Review of the relationship between the Crown and Te Kohanga Reo National Trust". Her current research projects are on parental involvement in children's learning, an evaluation of early childhood equity funding, a best evidence synthesis on professional development for early childhood educators, and sustainable school improvement. She is also working on a PhD on how documentation of teaching and learning in early childhood centres can contribute to policy debate. 